Keller Péter

\title{
A másokért felajánlott élet motívuma Gárdonyi nőalakjaiban
}

\begin{abstract}
A tanulmány - a teljesség igénye nélkül - mutatja be, hogy Gárdonyi Géza munkáiban, szinte az első írásától az utolsóig, jelen van a másokért felajánlott élet motívuma. Ez azonban az alkotásokban korántsem sablonos. Ahogyan a Jézus-követésben lelkileg tökéletesedik az alkotó, úgy világosodik meg számára maga a titok: a szenvedésben születik a szeretetet. Ennek az eszmének egyik csúcspontja az Isten rabjai c. regénye; Szent Margit önként és ártatlanul vállalta hazájáért a bünhődést, hogy az Úr megkegyelmezzen nemzetének.

A tanulmány következésképpen rámutat arra is, hogy a másokért felajánlott élet motívuma - ahogy azt János apostol írja - nagyon mély keresztény üzenetként megjelenik többek között a Rómeó és Júlia, illetve a Varázshegy történetében is.
\end{abstract}

A másokért felajánlott élet a szeretettel összefüggő fogalom. Alapvetően keresztény gondolat. János apostol skáláján: „Nagyobb szeretete senkinek sincs annál, mint ha valaki életét adja barátaiért” (Jn 15:13).

Az anyaság, a szülők gyerekvállalása, de akár az emberi szolidaritás okán általános emberi tulajdonság is lehetne.

Úgy tünik mégsem az. Inkább a szentek attribútuma.

A világ nehezen veszi észre. Diana hercegnő és Teréz anya például majdnem egy időben haltak meg. ${ }^{1}$ A hercegnő mai napig beszédtéma, az életét másokért felajánló és feláldozó Teréz anya halálát szűkszavú közlemények adták tudtul. A sajtó ma is elvétve említi.

A másokért felajánlott élet motívuma Gárdonyi életművében vissza-visszatér. Ez nem véletlen, mert Dédapámat a kortársai keresztény írónak tartották, aki hitét beleviszi az irodalomba, örül neki. ${ }^{2}$

Nőalakjaival, nőábrázolásával már a kortárs kritikusok is foglalkoztak. Madarász Flóris Az én falumról szólva megemlíti, hogy Gárdonyi szerint „a virág szeretete, a maga iránt való gondosság, a mások iránt való figyelem már zsenge korban is megnyilatkozó igazi női tulajdonságok". (A gyerekek.) A kislányok szívének szeretnie kell valamit, ha rongy, ha fadarab. (A kék pille.) „A női és férfi lélek párhuzamos jellemzésének nagy, szerető gonddal kicsiszolt finomságai bámulatra ragadnak bennünket” - figyel fel az Ábel és Eszter kapcsán. ${ }^{3}$ Az Egri csillagok Holdfogyatkozás fejezetéből kiemeli, hogy a harcba „amazonlelkü egri nők is belevegyülnek. 〈...〉 A kivívott diadal után Gergely boldogan öleli keblére feleségét és a török rabságból kiváltott gyermekét". A láthatatlan ember zárójelenete hasonlóképp megragadja: 
„Zéta szeme most nyílik föl igazán. Fölismeri az őt szerető, hű, miatta szenvedő, neki rendelt nőt. Együtt kelnek útra Bizánc felé, mikor Attila városa már lángtengerben úszik, mintha csak nyugat felől hajnalodnék. Dsidsia felesége, őrzőangyala lesz." ${ }^{4}$

Az Isten rabjai kapcsán Madarász arra hívja fel a figyelmünket, hogy Margit alakjával szinte kedvet csinál az író az önfeláldozó szerzetesi élethez: „A modern író nagy érdeklődéssel járja be a hegyeket mozgató hit világát, lelkében tiszteletet fakaszt a legmagasztosabb eszményekért hevülők buzgalma s múve, amelyben ezt a modern olvasóközönség elé tárja, valósággal a vallásos ihlet szülötte." Ez a világ cseppet sem életidegen: „a kolostor falai között is velünk rokon, érző embereket mutat nekünk.” A regény címében szereplő rabság nem kerülendő kolonc, hanem az élet velejárója. Részben rajtunk áll, mi mellett köteleződünk el, illetve hogy azonosulni tudunk-e Fentről kapott feladatunkkal:

„....az első napok egyikén a budai kolostorból (Jancsi) Szikardus fráter kíséretében a szigetre megy, egy részeg emberrel találkoznak. »Íme - mondja Szikardus - ez a test rabja.« Később zsidó kalmárok mellett vezet el útjok. »Ezek a pénz rabjai« - magyarázza a fráter. A mellettük ellovagló bársonyruhás cifra urakat a pompa rabjainak nevezi. Szóval szerinte mindenki rab, még a király is, mert ő a nemzet rabja. Jancsi erre azt kérdezi, hogy hát akkor ők, a barátok, kinek a rabjai? »Mi az Isten rabjai vagyunk« - feleli társa." ${ }^{5}$

Kéky Lajos ${ }^{6}$ hasonlóképp felfigyelt a Gárdonyi által ábrázolt nőalakok sokféleségére és hiteles ábrázolására:

„El tudja lesni a boldog nőnek lélekbe mélyedő, meleg nézését s a boldogtalannak hideg, szomorú pillantását",

„Az anyai szeretetet kevés költőnk magasztalta melegebb szavakkal, de a léha, üresszívű nőt is kevés gyülöli oly feneketlenül, mint Gárdonyi." ${ }^{8}$

Alakjai között kiemeli az éltető nap szimbolikájához köthető figurákat:

„Vannak jó, szeretettel áldott nők. Olyan ez, mint az ünnep a hétköznapok között. Megjelenése olyan, mint tavasszal az ablakon besütő napsugáré. Vidámságot hordoz magával és boldogító szót. Csupa finomság, csupa melegség, mintha nem is földi lélek volna."9

Balla Ignác az Új időkben közölt írásában a Szunyoghy Miatyánkjával kapcsolatban jegyzi meg, hogy az olvasók

„.... egy érdekes szerelmi regényt találnak Szunyoghy élettörténetében: egy férfi és két nő regényét. Ez a két nő azonban nem vetélytársnője egymásnak. Gárdonyi nemcsak, hogy nem szereti, de mint a hermelin a sarat, kerüli is az efféle banalitást. Ez a két nő maga a női nem, egyik a másiknak kiegészítő része és az ő Janus-Biformis arcukon minden nő lelke ott tükröződik. Az egyik nő az odaadó hitves, a másik a könnyelmű feleség, aki a férjet nem tudja megérteni és elcseréli azzal, aki üres és léha, de aki többet foglalkozik vele, mint az életét munkában és a felesége gondtalan, boldog életének biztosításában verejtékező férj." ${ }^{10}$ 
Ebből kiviláglik, hogy Gárdonyi ábrázolásának archetipikus, örök aspektusokat megvilágító vonásai ragadták meg a kritikus figyelmét.

A kortárs kritikusok javarészt férfiak. Simon Lajos az általa szerkesztett $A z$ egri remete címú kötetben biztosan nem véletlenül Kosáryné Réz Lolától tesz közzé egy áttekintő dolgozatot éppen Gárdonyi nőalakjai címen, melyben feltűnik a szenvedés és a hazáért való önfeláldozás gondolata. Kosáryné szerint Gárdonyi csak „Egy szenvedést ismer el általánosságban: az anya szenvedését. Egy ambíciót ismer el általánosságban: a hazáért vagy a szerelmes párjáért való önfeláldozó küzdelmet. Ezt is csak úgy, ha a történelem szentesítette."11

Pintér Jenő általánosságában azt ragadja meg az író alakjaiból és stilisztikájából, írásait fémjelző belső gondolati magjából, hogy a mélyen érző lelki emberek ábrázolása ritka a modern írók között, így különös érdeme Gárdonyinak:

"Gárdonyi Géza rajzaiban, novelláiban, regényeiben megvan az, ami a modern írónak olyan nagy hiányossága a mélyen érző szív, a részvét és megindultság az üldözöttek és szerencsétlenek keservei iránt. Az emberi lelket minden rejtekében ismeri, a szenvedők fájdalmát költői ihlettel mutatja be. Föltámasztó ereje a régi idők megelevenítésében nem egyszer szinte látomásszerü."12

A szenvedést is vállaló mélyen érző alakok nem véletlenek. Dédapám sajátos emberfogalmából következnek. Ő agyagedénybe zárt Isten-sugárnak mondja az embert. Ebben a meghatározásban az Istensugár az állítmány. Férfi is, nő is egyformán Isten-sugár. A különbség az agyagedényben van. Bár a teremtésben Ádám az első, és az is tagadhatatlan, hogy Éva az, akit képes volt megkísérteni az ördög, Gárdonyi mégis úgy vélekedik, hogy „Ha csakugyan mink vagyunk a bibliai bukott angyalok, a férfi magasabbról bukott, mint a nő. De a nőnek a szárnyból többje maradt". ${ }^{13} \mathrm{Az}$ angyalhasonlattal Gárdonyi tudatosan felülemelkedik az agyagedényen, a testiségen és lelki síkon, a paradicsomi állapotra emlékeztető formájában magyarázza a különbséget férfi és nő között. Ami az emberben, férfiben és nőben egyaránt megmaradt tagadhatatlan érték, az a szárny. Az emberek közül a Bibliában szárnyat csupán - a Dédapám által annyira tisztelt - Szűz Mária kapott. Azért kapta, hogy megmenthesse az ÉLETET a sátántól (lásd Jel 12). Talán ez lehet az oka, hogy Gárdonyi elsősorban az anyaság okán tisztelte a hölgyeket: „A nőben mindig az anyát tiszteljük. Akkor is, ha még távol van az anyaság. Akkor is, ha már rég túl van rajta." ${ }^{14}$ Tisztelete korántsem a biológiai adottságra épül, hanem arra, hogy a nők - „Máriaságuk" okán-révén? - Isten szövetségesei a teremtésben és - szintén "Máriaságuk" okán - a megváltásban. Ilyen értelemben minden nő hétfájdalmú is, és boldogságos is. „A Végtelenség láthatatlan örök folyama érint meg mindig - mondja Gárdonyi -, ha anyát látok. Isten gyümölcsfája ő. Őreá száll virágul a Végtelenségből jött lélek. Az ő szíve véréből sző magának testet. Mindig érzem, hogy Isten megbízottja ő. Az Ég szivárványa (Isten szövetségének jele!) le, hogy ér, női vállat érint." ${ }^{15}$

A szintén kortárs kritikus Oláh Gábor szerint „a művészi alkotás lélektanában mindig izgató kérdés marad: mennyi megy át az emberből az íróba?”16 Meglátása szerint az „ember” - azaz Gárdonyi - azért vonult el Egerbe, hogy Goethe-hez hasonló jó „író" lehessen, létezésünk titkára adhasson magyarázatot:

„Magának él; annyira, hogy rá lehetne olvasni Goethe szavait: »Der Dichter muss ganz sich, ganz in seinen geliebten Gegenständen leben.«〈...〉 Elvonul a sokszavú és kevésszívű világtól, hogy a csönd és a magánosság örök-ihlető sátorában próbálja megoldani milliomodszor a nagy kérdést: mi hát az ember?" Maga is benne van és felismerhető az általa megfogalmazott 
lét-titokban, ami így hangzik: „A világosság szülte az életet. Az élet szülte az akaratot. Az akarat szülte a bűnt. A bűn szülte a szenvedést. A szenvedés szülte a szeretetet." ${ }^{17}$

Ennek az eszmefuttatásnak a tárgya - a másokért felajánlott élet - vonatkozásában Oláh Gábor arra a lényeges szempontra hívja fel a figyelmünket, ${ }^{18}$ hogy az, amit vizsgálunk, a Jézus-követő Gárdonyi számára azonos a létezés titkával, Krisztus megváltásának titkával, a keresztény öröm misztériumával. A boldogság Istentől eredő, de az ember számára paradoxnak tűnő igazságát, hogy másokért szenvedni öröm, Gárdonyi másutt így fogalmazza: „A boldogságot abban az iskolában tanuljuk meg, amelyikben a tanító-mesternek a neve: Szenvedés." ${ }^{19}$

Nem kívánok eltérni a témától - a nőalakoktól -, szükséges azonban jeleznem, hogy Dédapám minden ember, tehát nő és férfi létének célját és értelmét egyaránt a másokért való felajánlásban látta.

Gárdonyi leginkább a férfi-nő vonatkoztatási rendszerben beszél az önfeláldozásról.

Már az első regényében, az Álmodozó szerelemben (1886) megfogalmazódik. Sándor szerelméért llona elhagyja családját, mindenét, és új életet kezd. A második Gárdonyi-regény a Cyprián (1888) ennek ellentézise, ahol már utal az író arra, hogy nem minden áldozat kedves az Istennek: Jolán, a fiatal várúrnő elcsábítja a komoly hivatást érző fiatal szerzetest, Cypriánt, aki mindent odahagy, mindent megtagad, hogy elnyerje az ifjú hölgy kegyeit. Itt tételeződik égi és földi szerelem dichotómiája.

Az én falumban (1898) a testi vonzódás mellett szembetűnőek az elköteleződéssel járó szenvedések, lelki és érzelmi aspektusok is. A Haragosok Lidije egy életen át nem tudja megbocsátani a "hitvány" Paizs Jánosnak, hogy bár szerelmet ígért neki, asszonnyal jött haza a katonaságból. A mesgye-kőben, egy modern kori Rómeó és Júlia történetben megérezzük, hogy micsoda nehézség azoknak a fiataloknak a tervezett életáldozata, akiknek családjai egymással haragban állnak. A Tanács-kérés kilép a férfinő vonatkoztatási rendszerből. A szülők gyermekeikért vállalt határtalan áldozatvállalásának szinte eleve elrendelt kudarcáról szól: a „lenni vagy nem lenni”, a „tenni vagy nem tenni” feloldhatatlan ellentétéről, ami az emberbe kódolt ösztönös szeretet egyszerűsége okán fel sem merül a parasztemberben. Ő csak a gyereke érdekét tartja szem előtt, taníttatni akarja és nem látja, hogy jóságának következménye az lesz, hogy városivá váló gyereke számára kolonccá válik majd. Kevi Pál halála a hétköznapi hősökről szól. A dolgos parasztember egy másik családon segítve szenved halálos balesetet, áldozza fel magát másokért, de az unoka látásának örömével hunyja le szemét és még a halálával is küldetést visz véghez, mert hírt kell vinnie a már megérkezetteknek. Az András meg a kutyája címú írás túllép az emberen. Azt sugallja, hogy a teremtett természet velejárója, hogy az áldozathozatal meg nem értése embert, állatot egyaránt halálba tud kergetni. A Jégvirágokban a szakralitás eszméje ismét közvetlenül ölt testet: a másokért áldozatot vállalók lelki támasza és vigasza Mária. Köncölné, a magát a családjáért, gyerekeiért feláldozó anya a templomban a Hétfájdalmas Szűz előtt térdepel.

A Titkosnapló egy megjegyzése: „Leghatásosabb az olyan téma, amely mögött egy másik történet lappang, vagy valami olyan gondolat, amely a történet mögött világít." ${ }^{\prime 20}$ Ez bátorít bennünket, hogy az Egri csillagokban (1901) a hazáért való önfeláldozás mellett más üzenetet is keressünk. Nagy János Ádám vette észre, hogy a regény paradicsomi jelenettel indul. Ez a mozzanat sejteti, hogy Vicuska és Gergő története bibliai párhuzamot is rejthet. A háttérből világító gondolat, hogy kapcsolatainkban megélhetjük a bűnbeesés és a megváltás történetét, megtapasztalhatjuk, hogy a női angyalszárnyak valóban nagyobbak. A kezdő jelenetben Vicuska (azaz a bibliai Éva) csábít és Gergő elcsábul. Jumurdzsák véget vetni látszik a paradicsomi életnek, de Gergő visszaküzdi oda magát. Vicuska szárnyai nem tűnnek el Éváról. Gergely ugyanúgy csodálja 
őt, mint hajdan Gergő, oltalmazza életüket még akkor is, amikor Éva Jancsi okán akarva-akaratlan ismét tragédiát okoz. E szárnyak képesek küzdeni a folyton kísértő Jumurdzsákkal, képesek meghatni Dobót, képesek erőt adni a kardforgatáshoz. Éva angyalszárnyai leginkább abban mutatkoznak meg, amikor a kis Szelimet ő vezeti vissza anyjához. Éva szenvedései krisztusi szeretetet szültek.

A borban (1901) Juli nem csak Imréért, hanem az egész családjáért hoz áldozatot. Szinte újjá kell születnie, hogy ki tudja mondani: „Igyék... ha jólesik."

A láthatatlan ember (1902) jellegzetesen az önfeláldozások regénye, amelyben az Egri csillagoknál már markánsabban jelenik meg a bibliai háttér, a példabeszéd jelleg. Zétát feláldozzák a családért. Priszkosz mindent megtesz Zétáért. Zéta eszelősen ragaszkodik Emőkéhez. Emőke a szó szoros értelmében megőrül Attiláért. Egy jelentéktelennek tűnő szereplő, Dsidsia viszont elénk éli Szent Pál szeretethimnuszát, az igazi önfeláldozást: „A szeretet türelmes, a szeretet jóságos, a szeretet nem féltékeny, nem kérkedik, nem is kevély. Nem tapintatlan, nem keresi a maga javát, nem gerjed haragra, a rosszat nem rója fel. Nem örül a gonoszságnak, örömét az igazság győzelmében leli. Mindent eltür, mindent elhisz, mindent remél, mindent elvisel" (1Kor 13:4-7). Az Úr akaratát igazán csak Dsidsia érti. llyen értelemben ő a főszereplő. (A regényben való szereplései számát tekintve rá is mondhatjuk, hogy láthatatlan ember!) Ő ugyanis nem „bölcselkedő beszéddel” (1Kor 1:17) hirdeti az evangéliumot. Türelemmel hordozza keresztjét. Zétához hasonlóan bennünket is rádöbbent a kereszt bölcsességére (1Kor 1). Arra, hogy

„Isten $\langle. .$.$\rangle azt választotta ki, ami a világ szemében balga, hogy megszégyenítse a bölcseket, s$ azt választotta ki, ami a világ előtt gyönge, hogy megszégyenítse az erőseket, s ami a világ előtt alacsonyrendű és lenézett, azt választotta ki az Isten, a semminek látszókat, hogy megsemmisítse azokat, akik valaminek látszanak" (1Kor 1:18-31).

Az öreg tekintetes (1905) családi, prófétai és szakrális ${ }^{21}$ regény egyszerre. Az értelmes és az értelmetlen önfeláldozás szembeállítása, ellentézise. Az önfeláldozás lényegéről való elmélkedés. Csurgó a pozitív példa, aki mindenét odaadja, kivéve az elveit, a végsőkig kitart küldetése mellett és az Isten kimenekíti a világból. A lánya viszont a negatív példa. Félreérti házastársi szerepét. Helytelenül értelmezi az önfeláldozást. Romba dönti a családját.

Az Ábel és Eszter (1907) a temetői sírfelirat okán a Cypriánnak, az önfeláldozás szerencsétlen értelmezése okán kicsit $A z$ öreg tekintetesnek az újragondolása. Messze vagyunk az érzékiségtől. Lélek vágyik lélekre. A neveltetés, az engedelmesség, a kötelességtudat a hajtóerő, mint Csurgó lányánál. Eszter rossz döntéseket hoz. Nem a szeretett emberért áldozza fel magát. Viszont imádkozik! Ennek köszönhetően nem is történik tragédia. A Gondviselés az öreg napokra örömöket tartogat.

Az Isten rabjai (1908), ahogyan Cs. Varga István fogalmaz: „a nemzeti méretű engesztelődés remekműve..." Margit misztikus vallomása a substitutio-tanról. Ahogyan az lge, a Bárány élete árán váltságdíjat fizetett az emberiségért, elégtételt adott az összes bűnösért, úgy vállalta Szent Margit a mysterium passionis jegyében a magyarságért a kegyelem-, irgalomszerző megszentelődést, szenvedést: önként és ártatlanul búnhődött Magyarországért, hogy kiengesztelje az ég haragját, hogy az Úr kegyelmezzen a nemzetnek. Gárdonyi legjobban sikerült regényének ezt tartotta. ${ }^{22} \mathrm{~A}$ másokért felajánlott élet motívuma az Isten-haza-család értékhierarchia minden szintjén megjelenik. Margit nem olyan, mint Csurgó lánya, és nem olyan, mint Eszter. Tudja, hogy az Istennek, nem pedig az embereknek tetsző döntést kell hoznia, amikor az önfeláldozás a 
tét. Ilyen esetben a bennünk lévő Isten-sugár fénye kell hogy megvilágosítson bennünket, nem az agyagedények előírásait kell betartani. Ha így teszünk, Mária velünk van, mint ahogyan Margit mellett is mindig ott volt. A Nyulak szigetén lévő kolostorhoz közeledők Mária-éneket énekeltek:

\author{
Útonjárók szép csillaga \\ édességes Szűz Mária! \\ Téged dicsér a madár is. \\ Rózsán zengő méhbogár is!
}

Margit Máriához imádkozott cellájában, mielőtt kikosarazta Ottokárt. ${ }^{23}$ Margit tudatában van, hogy az önfeláldozás nem visszavonható. Az Isten színe előtt tett fogadalmat megmásítani nem lehet. ${ }^{24}$ Dédapámnak ebben az írásban mutatkozik meg legjobban, hogy a nők "Máriaságuk” okán szövetségesei Istennek, hogy egyszerre hétfájdalmúak és boldogok. Mielőtt Margit kikosarazza Ottokárt, Jancsi azt mondja Margitról: „....élőkép. Nem festő festette, Isten alkotta.” Úgy, mint Máriát. Mária is élőképpé válik a regény végén. Mária festett képében Jancsi Margitot látja, aki beavatja titkába, miért volt szükség az ő önfeláldozására, hogy a földi fájdalmak elviselése boldogságforrás.

A Hosszúhajú veszedelemről (1912) a cím alapján nem sejti az olvasó, hogy a „szárnyak” regénye. Férfié, nőé egyaránt. Dédapám szerette az ellentézist. Az utolsó novellába - a tizenharmadikba -, melynek címe Hol vagy Éva, rejtette a tanulságot. A házasság-fogalmunk rossz. „A házasság nem csupán boldogsági társasvállalat. Szenvedések is vannak az életben. Tehát az egybekelők azokra a szenvedésekre is vállalkoznak. Csakhogy addig ki-ki a maga baját szenvedte, az egybekelés után már a másik baját is. Nem minden hónap május. Vállaljuk, hogy együtt éljük át a májust, vállalnunk kell, hogy együtt éljük át a későbbi viharokat is, rossz terméseket, fagyokat, sovány éveket."

A Szunyoghy Miatyánkja (1913) annyiban emlékeztet az Álmodozó szerelemre, hogy Szunyoghy Dániel, a férfi főhős ugyanúgy megtapasztalja azt az örömöt és boldogságot, amit az jelenti, hogy „szárnyas angyala” érte ajánlja fel életét, és átéli azokat a kínokat, amikor megcsalják, mint az Álmodozó szerelemben Sándor. Az Álmodozó szerelemben a fiatal író még csak a tényeket láttatja, az idős múvész a Szunyoghy Miatyánkjában már tanít. A lét-titkot magyarázza: „Valami különös szép törvény az Istennek földi rendjében, hogy minden szerencsétlenségünkből valami jó fakad. Minden keserüségünkből valami édesség. Minden könnycseppünkből, valami boldogság. Minden szenvedés gyöngyöt terem. Néha mingyárt is. Néha napok múlván, vagy évek múlván, vagy talán csak a másvilágon, - de gyöngyöt terem minden szenvedés." ${ }^{25}$

A Ki-ki a párjával (1923) is a lét-titkot kutatja. A Varázshegy szakrális tartalommal bíró előfutára. Habocska nem filozofál. Jézus példáját követi. Feláldozza magát. Téli hóviharban, amikor senki ember nem fog be a kocsiba, ő, a tüdőbeteg a másik tüdőbetegért kocsiba ül és számára orvost hoz. Története példabeszéd arról, hogy "Nagyobb szeretete senkinek sincs annál, mint ha valaki életét adja barátaiért" (In 15:13).

Az Ida regénye (1925) talán az Ábel és Eszterre rímel. Ida is engedelmes. Apja akarata érdekében ajánlja, áldozza fel életét. Korábban és más jutalmat kap, mint Eszter. Megszereti Csabát, és Csaba is őt. Ez is szakrális regény. Ez is példabeszéd. Arról szól, hogy „akik Istent szeretik, azoknak minden javukra válik” (Róm 8:28), vagy Gárdonyi átiratában: „a Halál el-ne-csússz ösvényén 〈...〉 egy láthatatlan jóságos kéz van a kezünkön. Vezet."26 
Írásom terjedelme nem engedi meg valamennyi Gárdonyi-mű vizsgálatát. A kortárs kritikusok meglátásait ma is érvényesnek tartom. Gárdonyi reálisan látta az embert, nőt és férfit egyaránt. Janus-arcúságunk bűnbeesésünk következménye. Noha Éva vitte bűnbe Ádámot, Gárdonyi szerint mégis a nők Isten szövetségesei, társai a teremtésben, és áldozatvállalásra való képességük alapján a megváltásban is. A nagy lét-titok - hogy a szenvedés szülte a szeretetet - az emberi életben legkézzelfoghatóbban a férfinő kapcsolatban, illetve az anyaságban tapasztalható meg. A kortárs Oláh Gábor a történelmi regények kapcsán jegyezte meg, hogy a két fiatal szerelmes ismétlődő motívuma sablonosnak tűnhet, de mindjárt fel is tette a kérdést: „Baj ez a sablonosnak tetsző mesefonás?” Majd így válaszolt rá: „Attól függ minden: milyen művészettel ismétlődnek a »leit-motivumok«. Raffael Madonna-képein örökké visszatér Mária és a kis Jézus alakja, de hányféle körben, hányféle színben, hányféle változatban!"27

Dédapám minden nap olvasta az Újszövetséget. Nála az igehelyek a történeteiben példabeszédhez hasonló módon elbeszélt „leit-motívumok". A másokért felajánlott élet - a lét-titok - ilyen rendre visszatérő, de mindig másként festett - szinte a szó szoros értelmében vett - Mária- és Jézusalak az életmúben. Nem ismétlés és nem sablon. Nem is lehet az, hiszen maga mondja: „Múved csak annyira érték, amennyi benne az új, az értékes új, amit még előtted senki meg nem mondott, mert nem tudott. Új karakter, új érzés, új látás stb. És még azon túl is: a műved annyit ér, amennyi szeretet van benne valaki vagy valami iránt."28 A művek időrendi sorrendje rávilágít, hogy a másokért felajánlott élet motívuma egyre mélyülő szeretetről szóló tapasztalatokat, üzeneteket hordoz. A kezdeti írásokban a másokért felajánlott élet "csupán” azt jelenti, hogy elhagyja az ember atyját és anyját (Lásd Mk 10:7; Ef 5:31), adott esetben hivatását, hogy a másiknak ajándékozza magát. Aztán tágul a szeretetfogalom, a karakterek nemcsak a szerelmükért, hanem a szúk közösségükért, a családjukért, a hazájukért adják oda magukat. Majd eljut a lét-titok tapasztalatok továbbadásához. Azon elmélkedik, hogy magunkat másokért felajánlani, tehát helyesen és a világ számára is elfogadható módon szeretni borzasztóan nehéz. Ellenséges érzelmű családok esetében bűnnek tűnhet a szándék is, mint ahogy bűnként értelmezhető, ha valaki a saját döntését a szülői döntés elébe kívánja tenni, és mint ahogy ténylegesen bűn az, ha valaki nincs tisztában azzal, mikor nem szabad feláldoznia magát a másikért. Azzal is számolni kell, hogy bár az ember felajánlja magát, felajánlását a másik nem fogadja el, visszaél vele, kihasználja, hogy szeretik. Mégis biztat: kérjük Mária segítségét, tegyük a jót, vegyük észre, hogy bennünket egy láthatatlan kéz vezet, mi is képesek vagyunk önmagunkat legyőzni, magunkat másokért Istennek ajánlani, adott esetben életünket is a másiknak odaadni szeretetből. A Jézus-követés témakörének szenteltem Az élő Gárdonyi-arc című könyvemet. ${ }^{29}$

A másokért felajánlott életről való gondolkodás időbeli formálódása teljes összhangban van Dédapám Jézus-követő életével, amit Fiainak úgy túnik már megélt tapasztalatként így ajánl:

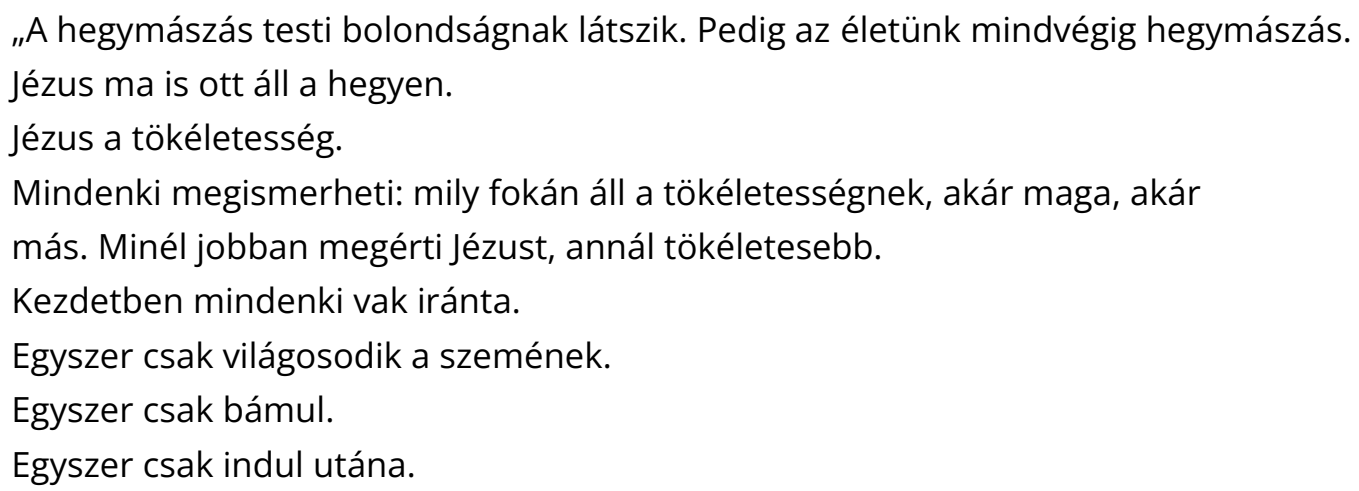


Mind a hegy körül vagyunk. Valamennyiünknek fel kell jutnunk valamikor a hegyre."30

A „hivatalos" irodalomtörténet rosszul állapítja meg, hogy a tizennyolc éves Gárdonyi Szőlősgyörökön megfogalmazott életelveivel „Franklin életútját tekinti példának". ${ }^{31}$ Dédapám életelvei között a Jézuskövetés a meghatározó elem. Erre reflektál, ennek sikerességét igazolja Tordai Ányos, az egri irodalomtörténész, a mindennapos jóbarát, a cisztercita szerzetes és paptanár, amikor azt állította: „Mi egriek följebb nem vihettük. De a jó Isten, hisszük, még magasabbra vitte." ${ }^{132}$

A múvész minden alkotása születésekor kicsit más ember. A keresztény művészre igazak a második Péter levél szavai: „Minden igyekezetetekkel legyetek rajta, hogy hitetek megteremje az erényt, az erény a tudást, a tudás a magatok fölötti uralmat, a magatok fölötti uralom a jóban való kitartást, a jóban való kitartás a vallásos érzületet, a vallásos érzület a testvériességet, a testvériesség pedig a szeretetet. Mert ha ezek megvannak, és gyarapodnak bennetek, nem marad Urunkra, Jézus Krisztusra vonatkozó ismeretetek hatástalan és meddő.” (2Pét 1:5-7) Gárdonyi maga is mondja: „Kezdetben a művész önző célt szolgál, aztán magáért a művészetért dolgozik, aztán személyét is, művészetét is odaajándékozza a társadalomnak." ${ }^{133}$ Az írónak lelki fejlődése nyomon követhető a másokért magukat felajánló elkülönülő női karakterekbe rejtett üzenetekben. Ahogyan ő halad előre a titokfejtésben úgy születik benne az „Új karakter, új érzés, új látás”: „Műved csak annyira érték, amennyi benne az új, az értékes új, amit még előtted senki meg nem mondott, mert nem tudott. Új karakter, új érzés, új látás stb. És még azon túl is: a múved annyit ér, amennyi szeretet van benne valaki vagy valami iránt." ${ }^{\prime 34}$ 


\section{Jegyzetek}

${ }^{1}$ Diana hercegnő 1997. augusztus 31 -én, Teréz anya 1997. szeptember 5-én hunyt el.

2 Ravasz László: A láthatatlan ember. In: Az egri remete (szerk.: Simon Lajos), Budapest: Dante, 1933.

${ }^{3}$ Lásd MADARÁsz Flóris: Gárdonyi Géza. // Katolikus Szemle, 1909, 245-262; 358-373; 451-474. o.

${ }^{4}$ I. m.: 471. o.

${ }^{5}$ I. m.: 472. o.

${ }^{6}$ KÉkY Lajos: Gárdonyi Géza. Budapesti Szemle, 1914, № 158, 197-242., majd könyvalakban: KékY Lajos: Gárdonyi Géza. Budapest: Pallas Irodalmi és Nyomda R. T., 1926.

${ }^{7}$ KékY Lajos: Gárdonyi Géza. Budapesti Szemle, 1914, № 158, 222. o.

8 I. m.: 224. o.

${ }^{9}$ I. m.: 225. o.

${ }^{10}$ BaLLA Ignác: Szunyoghy Miatyánkja. // Új idők, 1916. április 30., 481. o.

${ }^{11}$ KosÁRYNé RÉz Lola: Gárdonyi nőalakjai. In: Az egri remete (szerk.: Simon Lajos). Budapest: Dante, 1932, 92-101. o.

12 PINTÉR Jenő: A magyar irodalom története: tudományos rendszerezés: 1-8. köt. Budapest: Stephaneum Nyomda és Könyvkiadó, 1930-1941, VIII. kötet, 440. o.

${ }^{13}$ GÁrdonyı Géza: Földre néző szem. Égre néző lélek. Budapest: Dante, é. n., 70. o.

${ }^{14} \mathrm{Uo}$.

${ }^{15} \mathrm{Uo}$.

${ }^{16}$ OLÁH Gábor: Írói arcképek, Budapest: Singer és Wolfner, 1910. https://mek.oszk.hu/11400/11477/11477.htm

${ }^{17}$ Forráselemzési téma is lehet, hogy honnan vehette át Oláh Gárdonyi jellemzésére Az emberiség története öt mondatban című szabadverset, ami Gárdonyi saját gyerekeinek szánt gondolata. Lásd GáRDoNyı Géza: Földre nézô szem. Égre néző lélek. Budapest: Dante, é. n., 186. o.

18 OLÁH Gábor: I. m.: https://mek.oszk.hu/11400/11477/111477.htm

${ }^{19}$ GÁRDonyı Géza: Földre néző szem. Égre néző lélek. Budapest: Dante, é. n., 190. o.

${ }^{20}$ GÁrdonyi Géza: Titkosnapló, Budapest: Szépirodalmi Könyvkiadó, 1974, 61. o.

${ }^{21}$ KeLLER Péter: Tettének oka... (Gondolatok Gárdonyi Géza Az öreg tekintetes címü kisregényéről). In: GÁRDonYı Géza: Az öreg tekintetes, Budapest: Szent István Társulat, 2019, 131-155. o. és // Anyanyelv és Irodalmi Nevelés, 2018, № 3-4, 5-23. o.

${ }^{22}$ GÁRDonyi József: Az élő Gárdonyi Il., Budapest: Dante, 1934, 91. o.

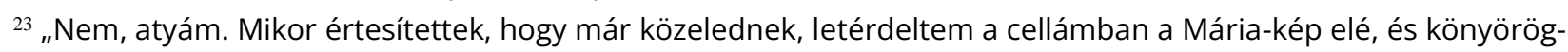
tem Máriának, hogy jöjjön velem, és ha szólnom kell, beszéljen a nyelvemmel. Akkor aztán bátran léptem be."

${ }_{24}^{24}$ "Ha már egyszer valaki apáca, és igazi apáca, vajon fontolgathat-e azon, hogy ne legyen apáca?"

${ }^{25}$ GÁRDONYI Géza: Szunyoghy Miatyánkja, Budapest: Singer és Wolfner, 1917, 52. o.

${ }^{26}$ GÁRDOnYi Géza: Ida regénye. Budapest: Dante Könyvkiadó, é. n., 2. o.

27 OLÁH Gábor: Irrói arcképek, Budapest: Singer és Wolfner, 1910. https://mek.oszk.hu/11400/11477/11477.htm

${ }^{28}$ GÁRDonyi Géza: Titkosnapló, Budapest: Szépirodalmi Könyvkiadó, 1974, 57-58. o.

29 KeLLeR Péter: Az élő Gárdonyi-arc, Budapest: Szent István Társulat, 2015.

${ }^{30}$ GÁrDonyı Géza: Földre néző szem. Budapest: Dante, é. n., 120. o.

${ }^{31}$ KISPÉTER András: Gárdonyi Géza, Budapest: Gondolat, 1970, 13. o.

32 ToRDAl Ányos: Gárdonyi utolsó napjaiból, Naplójegyzetek. // Élet, (XIII évf.) №23 (1922. november 12.)

${ }^{33}$ GárDonyi Géza: Titkosnapló, Budapest: Szépirodalmi Könyvkiadó, 1974, 49. o.

${ }^{34}$ Gárdonyi Géza: I. m. 57-58. o. 